\title{
Influence of time of day on measurement with chlorophyll meters and canopy reflectance sensors of different crop $\mathrm{N}$ status
}

\author{
Francisco M. Padilla ${ }^{1,2}$ (D) Romina de Souza ${ }^{1} \cdot$ M. Teresa Peña-Fleitas ${ }^{1} \cdot$ Rafael Grasso $^{3}$. \\ Marisa Gallardo ${ }^{1,2} \cdot$ Rodney B. Thompson ${ }^{1,2}$
}

Published online: 23 February 2019

(c) The Author(s) 2019

\begin{abstract}
Optical sensors are a promising approach for assessing nitrogen $(\mathrm{N})$ status of vegetable crops. However, their potential may be undermined if time of day influences measurements. This study evaluated the effects of time of day and $\mathrm{N}$ addition on measurements, made with two chlorophyll meters, SPAD-502 and MC-100, and two active canopy reflectance sensors, GreenSeeker handheld and Crop Circle ACS-470. Three treatments (N1, deficient, $\mathrm{N} 2$, conventional, and N3, excessive $\mathrm{N}$ application) of $\mathrm{N}$ concentration in the nutrient solution were applied by fertigation throughout a sweet pepper crop grown in soil in a greenhouse. Time of day of 12:00 and 15:00 h had an effect on measurements made with the SPAD-502, but only in the N1 treatment, suggesting that the effects of time of day were related to crop $\mathrm{N}$ status. This effect was slight, being 1.7 \pm 0.02 SPAD units lower at 12:00 and 15:00 h compared to at 9:00 h (relative decrease of 3.6\%). For the MC-100, a slight increase in Chlorophyll Content Index (CCI) values of $3.3 \pm 0.1$ units (relative increase of $6.3 \%$ ) was observed at 15:00 and 18:00 h, relative to CCI values at 9:00 h, regardless of $\mathrm{N}$ treatment. The time of day effect on chlorophyll meters appears to be negligible in relation to the wide range of values measured in greenhouse-grown sweet pepper. Normalized Difference Vegetation Index, measured both with the GreenSeeker and Crop Circle, and Green Normalized Difference Vegetation Index, measured with the Crop Circle, were not affected by time of day in any of the $\mathrm{N}$ treatments, showing that these sensors and indices can be used with confidence at any time of the day.
\end{abstract}

Keywords Irradiance - Optical sensors · Solar radiation - Sweet pepper · Vegetable crops · Vegetation indices

Electronic supplementary material The online version of this article (https://doi.org/10.1007/s1111 9-019-09641-1) contains supplementary material, which is available to authorized users.

Francisco M. Padilla

f.padilla@ual.es

Extended author information available on the last page of the article 


\section{Introduction}

Nitrogen $(\mathrm{N})$ fertilizer is applied in large amounts in vegetable production to ensure high yields (Meisinger et al. 2008; Neeteson 1994). Generally, only a minor part of applied N is recovered by crops, and the excess $\mathrm{N}$ is susceptible to loss to the environment where it is associated with various environmental problems (Cameron et al. 2013; Padilla et al. 2018b; Soto et al. 2015). Optimal $\mathrm{N}$ fertilization of vegetable crops, in respect to both quantity and timing, would benefit appreciably from accurate assessment of crop $\mathrm{N}$ status (Thompson et al. 2017). Traditional approaches to vegetable crop $\mathrm{N}$ management have been fertilizer recommendation schemes based on soil, and also on plant analysis (Fox and Walthall 2008; Schröder et al. 2000; Thompson et al. 2017). While these procedures are useful, the analyses are time-consuming, and commonly the time to obtain laboratory results prevents timely adjustments of fertilizer applications (Gianquinto et al. 2011a, b).

Proximal optical sensors are a promising approach for rapid and periodic assessment of crop N status (Padilla et al. 2018c; Usha and Singh 2013). Proximal optical sensors are a form of sensing in which the sensors are positioned either in contact with or close to the crop (Padilla et al. 2018c; Thompson et al. 2017). They can be used any time during the growth cycle or at certain phenological stages on commercial farms, require limited labor, and can be integrated with fertilizer decision making procedures (Gianquinto et al. 2011a, b). Optical sensors do not directly measure the $\mathrm{N}$ content in plant tissue, but provide assessment of either (a) indicator compounds, such as measurement with chlorophyll meters, or (b) indices of radiation characteristics, such as measurement with canopy reflectance sensors (Padilla et al. 2018c; Samborski et al. 2009). Both types of assessment are sensitive to crop N status (Fox and Walthall 2008; Samborski et al. 2009; Tremblay et al. 2012).

Chlorophyll meters indirectly estimate relative chlorophyll content per unit of leaf surface area (Monje and Bugbee 1992; Padilla et al. 2018a, c). All chlorophyll meters are generally easy to use, do not require any specific training of users, and make measurements very rapidly with very little data processing (Gianquinto et al. 2004). Given their ease of use, small size and relatively low cost, chlorophyll meters are very well-suited for on-farm use to provide rapid assessment of vegetable crop N status (Padilla et al. 2018c). However, given the relatively small sampling area, appreciable repetition and strict sampling protocols have been developed for their practical use (Gianquinto et al. 2011b; Padilla et al. 2015; Samborski et al. 2009).

Canopy reflectance sensors provide information on crop $\mathrm{N}$ status by measuring specific wavelengths of radiation absorbed and reflected from crop foliage (Hatfield et al. 2008; Ollinger 2011; Peñuelas et al. 1994). Being proximal optical sensors, they are positioned relatively close to the crop, e.g. 0.4-3.0 m from the crop canopy (Padilla et al. 2018c). The wavelengths used commonly correspond to four narrow bands centered around $675 \mathrm{~nm}$ (maximum absorption of red), $905 \mathrm{~nm}$ (maximum reflection of near infrared (NIR)), $720 \mathrm{~nm}$ (mid portion of the red-edge range), and $550 \mathrm{~nm}$ (maximum reflectance of green) (Gianquinto et al. 2011a, b; Read et al. 2002; Thenkabail et al. 2002). To increase the sensitivity to specific biophysical characteristics and reduce variability, spectral vegetation indices combining spectral reflectance from 2 to 3 wavelengths are commonly used (Bannari et al. 1995; Scotford and Miller 2005). Canopy reflectance sensors are classified as passive or active sensors depending on whether they have their own light source. For passive reflectance sensors, uniform irradiance conditions are highly recommended (Oliveira and Scharf 2014). An intended advantage of active reflectance sensors is that there may be no special requirement for uniform irradiance conditions (Solari et al. 2008). 
The use of absolute sufficiency values for chlorophyll meters measurements (Gianquinto et al. 2004, 2006; Güler et al. 2006; Padilla et al. 2015, 2017a) and of vegetation indices, measured with canopy reflectance sensors (Padilla et al. 2015, 2017b), have been proposed as practical procedures to assist with $\mathrm{N}$ management of vegetable crops (Padilla et al. 2018c; Thompson et al. 2017). However, the potential value of absolute sufficiency values for crop $\mathrm{N}$ management may be reduced if environmental conditions influence measured values (Thompson et al. 2017). Practical use of optical sensors to assist with $\mathrm{N}$ fertilization requires that measurements are precise and reproducible throughout the day regardless of environmental conditions (Martínez and Guiamet 2004; Oliveira and Scharf 2014).

Time of day and underlying changes in solar irradiance can influence chlorophyll meter measurements (Hoel and Solhaug 1998; Martínez and Guiamet 2004; Xiong et al. 2015). Higher values of chlorophyll meters have been measured at lower irradiance conditions, in winter wheat (Hoel and Solhaug 1998; Martínez and Guiamet 2004), rice (Xiong et al. 2015), tobacco (Nauš et al. 2010) and soybean (Xiong et al. 2015). The influence of irradiance on chlorophyll meter measurements may be species-specific, depending on species adaptation to high irradiance (Mamrutha et al. 2017). For instance, measurements of various chlorophyll meters were not significantly influenced by diurnal variation in irradiance in six spring wheat genotypes (Mamrutha et al. 2017).

Active canopy reflectance sensors are intended to be able to measure at any time of day regardless of variations in solar irradiance (Fitzgerald 2010; Kipp et al. 2014; Solari et al. 2008). However, there are studies indicating that active sensors can be influenced by the time of day (Kim et al. 2012; Oliveira and Scharf 2014; Teixeira Crusiol et al. 2017). Lower NDVI values were reported at solar noon, compared to early morning or late in the day, in soybean (Teixeira Crusiol et al. 2017), turfgrass (Kim et al. 2012) and cotton (Oliveira and Scharf 2014).

Standardization of time of day and irradiance conditions when making optical sensor measurements is recommended for comparison of sequences on a given crop (Padilla et al. 2018c). The general recommendation is for optical sensor measurements to be made at the same time of day under clear skies (Gianquinto et al. 2004). In commercial farming, restricting measurements, to such conditions, would be practically difficult where farm work has to be scheduled considering numerous management activities. For the practical use of optical sensors, it is necessary to understand the influence of time of day on optical sensor measurement.

The establishment within a crop of a well-fertilized plot without $\mathrm{N}$ limitations, usually called the reference plot, has been widely suggested as a way to reduce time of day effects on sensor measurements (Holland and Schepers 2013; Zhu et al. 2011). In this approach, optical sensor measurements made in the crop are divided by measurements taken in the reference plot, the result being called Nitrogen Sufficiency Index (NSI) (Debaeke et al. 2006; Piekielek et al. 1995). The influence of factors other than $\mathrm{N}$ on optical sensor measurements are minimized as effects will be very similar in both the measured crop and the reference plot. However, the use of reference plots in fertigated horticultural crops is impractical for technical reasons (Padilla et al. 2018c), and nearly all studies with optical sensors in fertigated vegetable crops have used absolute values (Padilla et al. 2018c).

The objectives of this study were to assess the effects of time of day on measurements of chlorophyll meters and active canopy reflectance sensors. Sweet pepper was chosen because of its high chlorophyll content (Parry et al. 2014) ensuring a wide range of measurement values.

Three treatments of increasing $\mathrm{N}$ concentration in the nutrient solution were applied throughout the crop by fertigation. There was a very deficient $\mathrm{N}$ treatment, a conventional 
$\mathrm{N}$ management treatment, that was regarded as being close to optimal, and a very excessive $\mathrm{N}$ treatment.

\section{Materials and methods}

\section{Experimental site}

A sweet pepper (Capsicum annuum 'Melchor') crop was grown in soil in a plastic greenhouse. The experimental work was conducted at the Experimental Station of the University of Almeria (SE Spain, 36 $51^{\prime} \mathrm{N}, 2^{\circ} 16^{\prime} \mathrm{W}$ and $92 \mathrm{~m}$ elevation). The greenhouse had polycarbonate walls and a roof of low density polyethylene (LDPE) tri-laminated film $(200 \mu \mathrm{m}$ thickness) with transmittance to photosynthetically active radiation (PAR) of approximately $60 \%$. It had no heating or artificial light, had passive ventilation (lateral side panels and flap roof windows), and an east-west orientation, with crop rows aligned north-south. The cropping area was $1300 \mathrm{~m}^{2}$.

The soil was an artificial layered "enarenado" soil (Thompson et al. 2007), consisting of a $300 \mathrm{~mm}$ layer of imported silty loam texture soil placed over the original loam soil and a $100 \mathrm{~mm}$ layer of fine gravel (mostly $2-5 \mathrm{~mm}$ diameter) placed on the imported soil as a mulch. At greenhouse construction in July 2007, $200 \mathrm{~m}^{3} \mathrm{ha}^{-1}$ of sheep manure $(63 \%$ dry matter, $1.7 \%$ total $\mathrm{N}$ content and $0.7 \mathrm{t} \mathrm{m}^{-3}$ density) was mixed into the top layer of the imported soil, prior to adding the gravel layer, consistent with established local practice (Thompson et al. 2007).

Above-ground drip irrigation was used for combined irrigation and mineral fertilizer application. Drip tape was arranged in paired lines with $0.8 \mathrm{~m}$ spacing between lines within each pair, $1.2 \mathrm{~m}$ spacing between adjacent pairs of lines, and $0.5 \mathrm{~m}$ spacing between drip emitters within drip lines, giving an emitter density of 2 emitters $\mathrm{m}^{-2}$. The emitters had a discharge rate of $3 \mathrm{~L} \mathrm{~h}^{-1}$.

The greenhouse was organized into a total of 24 plots, measuring $6 \mathrm{~m} \times 6 \mathrm{~m} ; 12$ plots were used in the current study. There were three $\mathrm{N}$ treatments with four replicate plots per treatment, arranged in a randomized block design. Each plot contained three paired lines of plants (six lines of plants in total), with 12 plants in each line with a $0.5 \mathrm{~m}$ spacing. Separation between the two lines that made the paired line of plants was $0.8 \mathrm{~m}$, and separation between two paired lines was $1.2 \mathrm{~m}$. One plant was positioned $60 \mathrm{~mm}$ from and immediately adjacent to each dripper, giving a plant density of 2 plants $\mathrm{m}^{-2}$ and 72 plants per replicate plot. The greenhouse was divided longitudinally into northern and southern plots by a $2 \mathrm{~m}$ wide path along its east-west axis; there were two complete blocks in each of the northern and southern side of the greenhouse. There were border areas along the edges of the greenhouse.

\section{Sweet pepper crop}

The sweet pepper crop was grown with a summer-winter growing cycle in 2017-2018. The crop was grown from transplanted five-week-old seedlings, from 21 July 2017 to 20 February 2018 (cropping period of 214 days).

There were three treatments of different $\mathrm{N}$ concentration in the nutrient solution, applied by fertigation, that commenced 10 days after transplant (DAT). The treatments were applied in every irrigation throughout the crop. The $\mathrm{N}$ treatments were very $\mathrm{N}$ deficient 
(N1), conventional $\mathrm{N}$ management (N2), and very excessive $\mathrm{N}$ (N3), according to the $\mathrm{N}$ concentration in the applied nutrient solution. The average applied $\mathrm{N}$ concentrations in $\mathrm{N} 1$, $\mathrm{N} 2$ and $\mathrm{N} 3$ treatments during the crop were 2.0, 9.7 and $17.1 \mathrm{mmol} \mathrm{N} \mathrm{L}^{-1}$, respectively. Considering the total irrigation volume per treatment, the total applied $\mathrm{N}$ amounts in $\mathrm{N} 1$, $\mathrm{N} 2$ and $\mathrm{N} 3$ treatments were 86,519 and $1198 \mathrm{~kg} \mathrm{~N} \mathrm{ha}^{-1}$, respectively. Other than $\mathrm{N}$, complete nutrient solutions were applied to all three treatments to ensure that the other macro, secondary and micro-nutrients were not limiting. For all treatments, most $\mathrm{N}$ was applied as nitrate $\left(\mathrm{NO}_{3}{ }^{-}\right)$, the rest as ammonium $\left(\mathrm{NH}_{4}^{+}\right)$.

Plants were managed following local practice. The crop was physically supported using a system of nylon cords placed vertically and horizontally along the side of the crop. Irrigation was scheduled to maintain soil matric potential (SMP) in the root zone, at $120 \mathrm{~mm}$ depth, within -15 to $-25 \mathrm{kPa}$; one tensiometer (Irrometer, Co., Riverside, Ca, USA) per plot was used to measure SMP. High temperature within the greenhouse was controlled by white-washing the plastic cladding with $\mathrm{CaCO}_{3}$ suspension, 8 days before transplanting $\left(0.5 \mathrm{~kg} \mathrm{~L}^{-1}\right)$ and 34 days after transplanting $\left(0.40 \mathrm{~kg} \mathrm{~L}^{-1}\right)$. The white-washing was removed 68 days after transplanting.

\section{Optical sensor measurements}

Optical sensor measurements commenced on 27 September 2017 and were repeated every 17 days, on average, throughout most of the crop, until 12 January 2018, for a total of six measurement dates: 27 September (68 DAT), 10 October (81 DAT), 26 October (97 DAT), 9 November (111 DAT), 5 December (137 DAT) and 12 January (175 DAT). Optical sensor measurements were made, each day of measurement, at 9:00, 12:00, 15:00 and 18:00 h solar time; these times are hereafter referred to as early morning, midday, afternoon and evening, respectively.

Measurements of relative chlorophyll content were made with two leaf-clip chlorophyll meters, the SPAD-502 meter (Konica Minolta, Inc., Tokyo, Japan) and the MC-100 Chlorophyll Concentration Meter (Apogee Instruments, Inc., Logan, UT, USA). The measurement areas of each meter were $6 \mathrm{~mm}^{2}$ for the SPAD-502 and $63.6 \mathrm{~mm}^{2}$ for the MC-100. The two meters determine the relative content of chlorophyll by measuring light absorbance in the red and NIR; the SPAD-502 measures absorbance at $650 \mathrm{~nm}$ (red) and $940 \mathrm{~nm}$ (NIR), and the MC-100 at $653 \mathrm{~nm}$ and $931 \mathrm{~nm}$. Using the two absorbance values, the meters calculate a dimensionless numerical value which is related to the chlorophyll content (Padilla et al. 2018a). The equations employed by SPAD-502 meter to calculate the numerical value are confidential (Parry et al. 2014). The MC-100 calculates a ratio between transmission of radiation at $931 \mathrm{~nm}$ divided by transmission of radiation at $653 \mathrm{~nm}$, the result being called the Chlorophyll Content Index (CCI). Measurement output for the SPAD-502 meter are SPAD units and for the MC-100 meter are CCI values.

Individual measurements with each meter were made on eight different plants in each of the four replicate plots of the three $\mathrm{N}$ treatments. These plants were located in the two central lines of plants in each plot; four plants were measured per line. One measurement per plant was made on the most recently fully expanded and well-lit leaf, on the distal part of the adaxial (top) side of the leaf, midway between the margin and the mid-rib of the leaf. Leaves with physical damage or with condensed water were not measured, alternative plants were selected.

Measurements of crop canopy reflectance were made with the GreenSeeker handheld sensor (Trimble Navigation Limited, Sunnyvale, CA, USA) and the Crop Circle ACS-470 
sensor (Holland Scientific, Inc., Lincoln, NE, USA). These are active canopy reflectance sensor fitted with their own polychromatic light sources (Solari et al. 2008). Both sensors were held vertically parallel to the crop rows, having a side view of the upper part of the foliage. The sensors were positioned so that the top of the field of view was level with the most recently fully expanded leaf. Measurements commenced once the crop had sufficient height to avoid sensing of soil reflectance, considering the field of view of each sensor.

Measurements with the GreenSeeker handheld sensor were made at $600 \mathrm{~mm}$ horizontal distance, giving an oval field of view with a height of $\approx 250 \mathrm{~mm}$. One-shot measurements per plant were made by placing the sensor in front of each of eight plants in each replicate plot, the four plants were in each of the two inner lines of plants in each plot. The value for each plot was the average of the eight measurements. This sensor calculates the Normalized Difference Vegetation Index (NDVI; Table 1) by measuring crop reflectance at two wavelengths, $780 \mathrm{~nm}$ (NIR) and $660 \mathrm{~nm}$ (red).

Canopy reflectance measurements with the Crop Circle ACS-470 sensor were made at a $450 \mathrm{~mm}$ horizontal distance, giving a field of view of $\approx 260$ (vertical) $\times 50$ (horizontal) $\mathrm{mm}$. In each measurement, two passes consisting of a $4 \mathrm{~m}$ pass in each of the two inner lines of plants were made at walking speed (approx. at $1.5 \mathrm{~km} \mathrm{~h}^{-1}$ ). Ten measurements were made per second, giving approximately 200 individual measurements per plot. The filters selected to measure reflectance were $550 \mathrm{~nm}$ (green), $670 \mathrm{~nm}$ (red) and $760 \mathrm{~nm}$ (NIR). Reflectance data of each wavelength were stored in a portable GeoScout GLS-400 datalogger (Holland Scientific, Inc.) and subsequently processed. From each individual measurement, vegetation indices were calculated based on the reflectance of each wavelength (Table 1); the values of the vegetation index for individual measurements were averaged to provide an average vegetation index value for each replicate plot.

\section{Air temperature, solar radiation and photosynthetically active radiation (PAR)}

Air temperature in the greenhouse was measured with a ventilated aspirated psychrometer (model 1.1130, Thies Clima, Göttingen, Germany) and solar radiation with a pyranometer (model SKS 1110, Skye Instruments, Llandrindod Wells, Wales, UK). Both devices were placed in a shadow-free location of the greenhouse over the crop canopy. All data were recorded and stored using a data logger (CR10X, Campbell Scientific, Inc., Logan, UT, USA).

The photosynthetically active radiation (PAR) over the crop canopy was measured at the time of optical sensor measurements, using a linear quantum sensor (model LP-80, Decagon Devices, Inc., Pullman, WA, USA). Each PAR value consisted of the

Table 1 Vegetation indices calculated from canopy reflectance measurements made with the Crop Circle ACS-470 sensor in a sweet pepper crop grown in a greenhouse

\begin{tabular}{llll}
\hline Vegetation index & Abbreviation & Equation & Reference \\
\hline Normalized difference vegetation index & NDVI & $\frac{\text { NIR-Red }}{\text { NIR+Red }}$ & Sellers (1985) \\
Green normalized difference vegetation index & GNDVI & $\frac{\text { NIR-Green }}{\text { NIR+Green }}$ & Gitelson et al. (1996) \\
Red ratio vegetation index & RVI & $\frac{\text { NIR }}{\text { Red }}$ & Birth and McVey (1968) \\
Green ratio vegetation index & GVI & $\frac{\text { NIR }}{\text { Green }}$ & Birth and McVey (1968) \\
\hline
\end{tabular}

NIR (Near infrared) 760 nm; Red 670 nm; Green 550 nm 
average of two measurements, taken at the beginning and at the end of optical sensor measurements each time. Measurements were made by placing the linear quantum sensor horizontally over a line of plants located in the center of each replicate plot per treatment.

\section{Data analysis and statistics}

Exploratory repeated-measure analysis of variance (RM-ANOVA) were conducted to test the effect of time of day $(9: 00,12: 00,15: 00$ and 18:00 h), N treatment $(\mathrm{N} 1, \mathrm{~N} 2$ and N3), date of measurement $(68,81,97,111,137$ and 175 DAT), and their two- and three-term interactions, on optical sensor measurements, using date of measurement as a within-subjects factor, and time of day, $\mathrm{N}$ treatment and block as between-subjects factors (Tables S1 and S2). The results of these analyses showed that the threeterm Nitrogen $\mathrm{x}$ Time $\mathrm{x}$ Date interaction was not significant at $\mathrm{P} \geq 0.68$ for all optical sensor measurements (Tables S1 and S2), and the two-term Time x Date interaction was not significant at $\mathrm{P} \geq 0.39$ for all optical sensor measurements but RVI (Tables $\mathrm{S} 1$ and S2). These generally not significant two- and three-term interactions showed that the effects of time of day on optical sensor measurements were independent of the date of measurement. Given these results, and to provide a clear representation of the data, integrated values of optical sensor measurements, which integrated data from the six measurement dates into a unique value, were calculated following Padilla et al. (2017b).

Integrated values (IV) of PAR and optical sensor data, for the six sampling dates, were obtained by calculating a weighted average value for each replicate plot, for each time of day. The IV was calculated as an average of the individual values (iv) of each measurement date pondered by the time elapsed between two consecutive measurements (Padilla et al. 2017b), as:

$$
\mathrm{IV}=\sum \mathrm{iv}_{\mathrm{m}} \cdot \mathrm{d}_{\mathrm{m}} / \mathrm{D}
$$

where $i v_{m}$ was the individual value at each date of measurement $m, d_{m}$ was the number of days since the previous measurement, and $\mathrm{D}$ was the total number of days from first to last measurement. On the first date of measurement, when there was no preceding measurement, a seventeen-day interval was assumed because that was the average frequency throughout most of the crop.

To represent the variation in PAR and optical sensor measurements during the day, the relative changes in measurements made at 12:00, 15:00 and 18:00 $\mathrm{h}$ to those made at 9:00 $\mathrm{h}$ were calculated as percentages.

Significant effects of time of day (9:00, 12:00, 15:00 and 18:00 h) and $\mathrm{N}$ treatment (N1, N2 and N3), and their interaction, on integrated PAR and integrated optical sensor measurements were evaluated by RM-ANOVA, using time of day as a within-subjects factor, and $\mathrm{N}$ treatment and block as between-subjects factors.

When necessary to meet the homoscedasticity assumption of ANOVA, transformed values were used. The statistical package IBM SPSS 22 (IBM Corporation, Armonk, NY, USA) was used. Significant differences were considered to occur at $\mathrm{P}<0.05$, followed by LSD pair-wise comparison tests. 

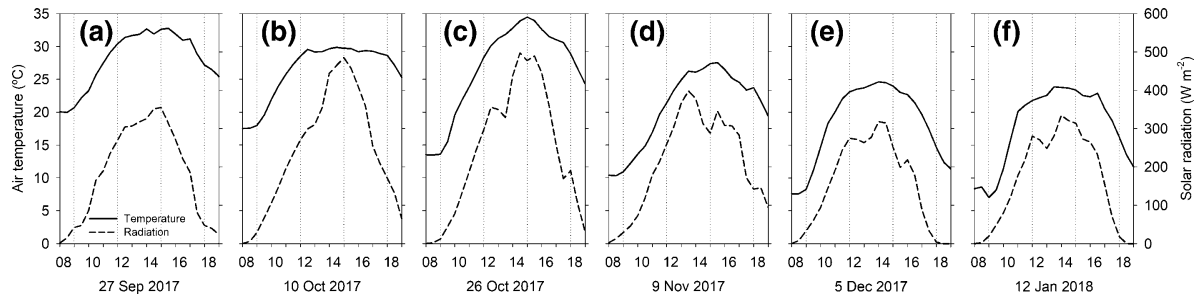

Fig. 1 Diurnal evolution of air temperature $\left({ }^{\circ} \mathrm{C}\right.$; solid line), on main y-axis, and solar radiation $\left(\mathrm{W} \mathrm{m}{ }^{-2}\right.$; dotted line), on secondary y-axis, in the greenhouse, on the six dates of measurement. Vertical dotted lines show the time of day with optical sensor measurements, i.e. 9:00, 12:00, 15:00 and 18:00 $\mathrm{h}$

Fig. 2 Diurnal evolution of integrated photosynthetically active radiation (PAR) over a sweet pepper crop grown in greenhouse. Different lower-case letters show significant differences, at $\mathrm{P}<0.05$, between time of day, after LSD posthoc tests. Data have been pooled over the three different $\mathrm{N}$ treatments. Error bars show standard error

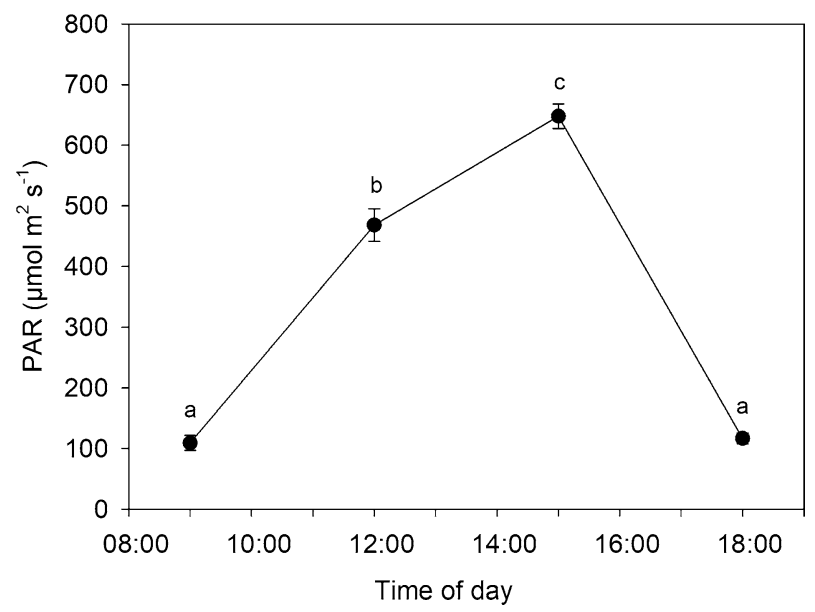

\section{Results}

\section{Temperature, solar radiation and PAR}

On most measurement dates, solar radiation in the greenhouse increased to maximum values at 14:00-15:00 $\mathrm{h}$, and then rapidly declined to negligible or small values by 18:00 (Fig. 1). During the daylight period, on all measurement dates, air temperature in the greenhouse, increased to maximum values at 12:00-15:00 h, after which it generally declined appreciably (Fig. 1).

During the daylight period, integrated PAR significantly increased (RM-ANOVA $\mathrm{F}=325.9, \mathrm{P}<0.001)$ reaching a maximum value at 15:00 h (Fig. 2). Integrated PAR at 18:00 h was not statistically different to that at 9:00 (Fig. 2). Similar integrated PAR levels were measured regardless of $\mathrm{N}$ treatment $\left(\mathrm{RM}-\mathrm{ANOVA}_{\mathrm{N}} \mathrm{F}=1.3, \mathrm{P}=0.333\right)$.

\section{Effect of nitrogen on chlorophyll meter and canopy reflectance measurements}

Measurements of both chlorophyll meters were very significantly affected by $\mathrm{N}$ treatment $\left(\mathrm{RM}_{-\mathrm{ANOVA}}, \mathrm{P}<0.001\right)$, regardless of time of day $\left(\mathrm{RM}_{\mathrm{N}} \mathrm{ANOVA}\right.$ Time $\times \mathrm{N}, \mathrm{P}>0.09$ for both meters). Chlorophyll meter measurements significantly increased with $\mathrm{N}$ addition; 
there were very significant differences from N1 to N2 treatments, and significant differences between the N2 and N3 treatments (Fig. 3).

Nitrogen treatment had a very strong effect on (a) NDVI values, measured with both the GreenSeeker handheld sensor (Fig. 4a) and the Crop Circle ACS-470 sensor (Fig. 4b), and (b) values of three other vegetation indices measured with the Crop Circle sensor, i.e.

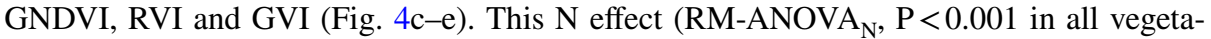
tion indices) occurred regardless of the time of day $\left(\mathrm{RM}^{-A N O V A_{\text {Time } \times \mathrm{N}}}, \mathrm{P}>0.05\right.$ in all vegetation indices). Values of all four vegetation indices increased significantly $(\mathrm{P}<0.05$ in all cases) with $\mathrm{N}$ addition from the $\mathrm{N} 1$ to $\mathrm{N} 2$ and $\mathrm{N} 3$ treatments. This effect was consistent for all four times of day (Fig. 4).

\section{Effect of time of day on chlorophyll meters}

With the SPAD-502 meter, there was a significant Time $\mathrm{x}$ Nitrogen interaction (Table 2), indicating that time of day had a significant effect on SPAD-502 measurements depending on the $\mathrm{N}$ treatment. In the $\mathrm{N} 1$ treatment, SPAD-502 values were significantly lower at 12:00 and 15:00 $\mathrm{h}$ than at 9:00 $\mathrm{h}$, while SPAD-502 values at 18:00 $\mathrm{h}$ were statistically

Fig. 3 Diurnal evolution of integrated SPAD (a) and CCI values (b), in a sweet pepper crop grown in greenhouse. Different uppercase letters show significant differences, at $\mathrm{P}<0.05$, between $\mathrm{N}$ treatments, regardless of time of day, after LSD posthoc tests. Error bars show standard error. CCI is Chlorophyll Concentration Index, measured with a MC-100 meter
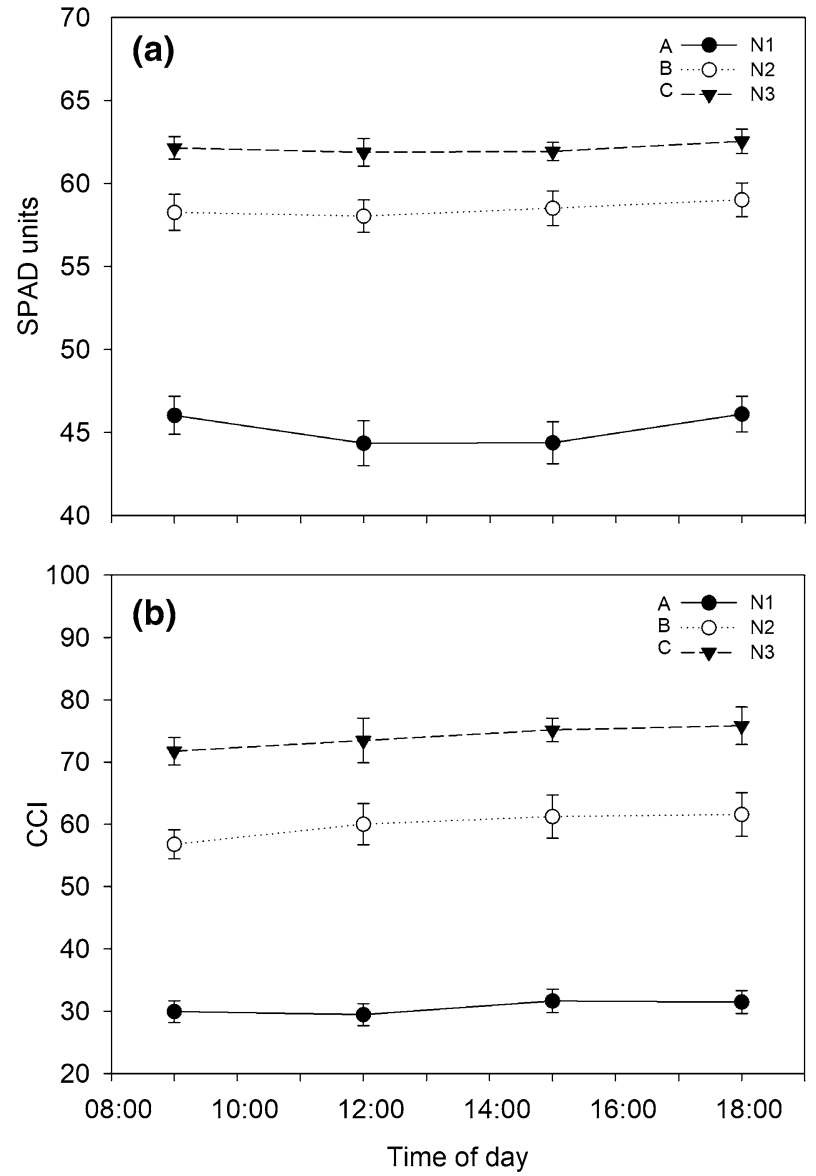

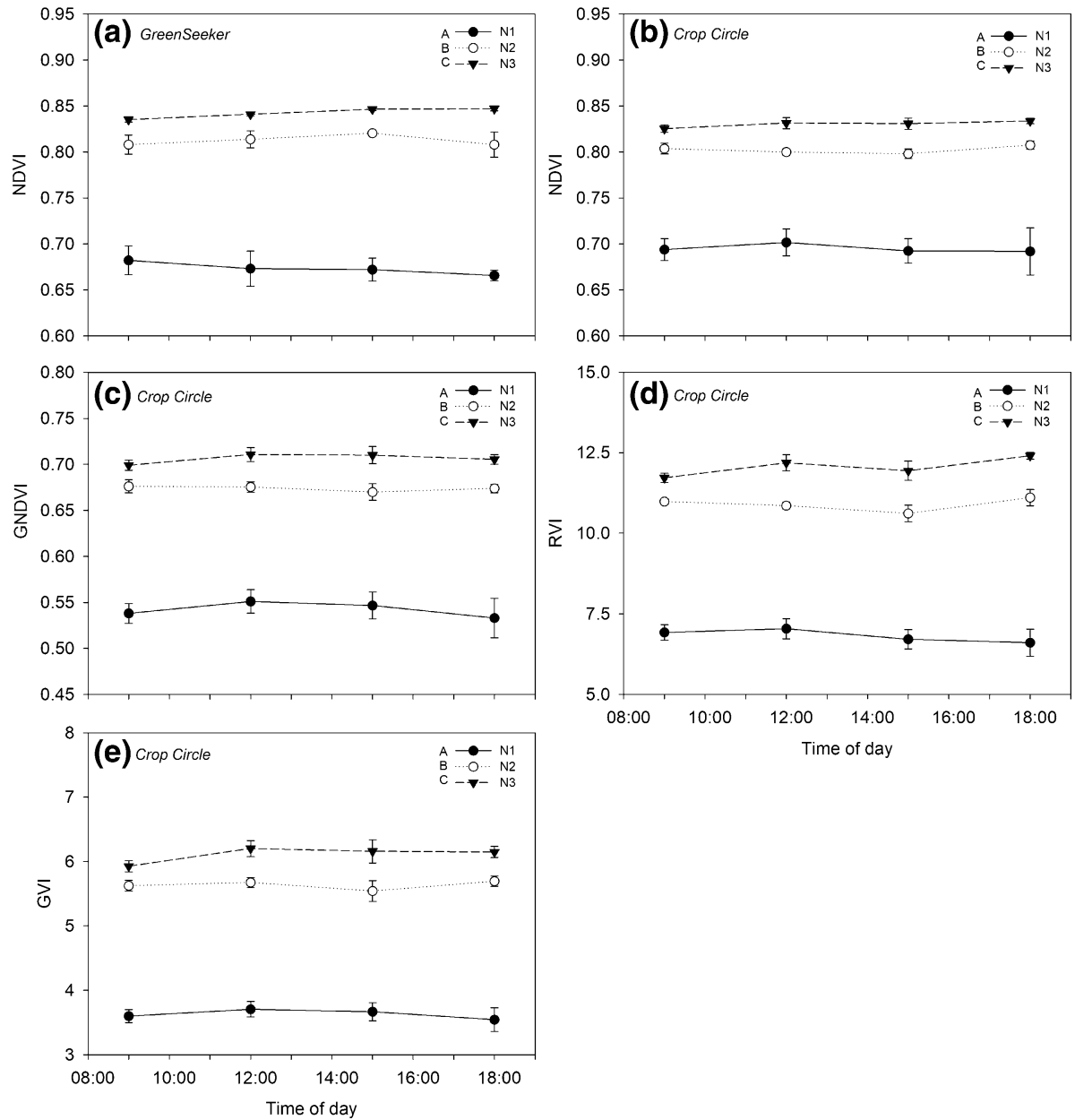

Fig. 4 Diurnal evolution of integrated NDVI values, measured with the GreenSeeker handheld (a) and with the Crop Circle ACS-470 (b), and of integrated GNDVI (c), RVI (d) and GVI (e) values, measured with the Crop Circle ACS-470, in a sweet pepper crop grown in greenhouse. Different upper-case letters show significant differences, at $\mathrm{P}<0.05$, between $\mathrm{N}$ treatments, regardless of time of day. Error bars show standard error

Table 2 Repeated-measure analysis of variance (RM-ANOVA) testing the effect of nitrogen treatment and time of day on change in integrated SPAD-502 and CCI values, relative to 9:00 h, in a sweet pepper crop grown in a greenhouse

\begin{tabular}{lrlrrrr}
\hline Effect & df & \multicolumn{2}{l}{ SPAD units } & & \multicolumn{2}{l}{ CCI } \\
\cline { 3 - 4 } \cline { 6 - 7 } & & & F & P & & \multicolumn{1}{l}{ F } \\
\hline Block & 3 & 0.81 & 0.533 & & 0.55 & 0.666 \\
Nitrogen (N) & 2 & 0.34 & 0.725 & & 0.09 & 0.917 \\
Time (T) & 3 & 9.29 & $<0.001$ & & 17.57 & $<0.001$ \\
N $\times \mathrm{T}$ & 6 & 3.31 & 0.023 & & 1.66 & 0.189 \\
Error & 18 & & & & & \\
\hline
\end{tabular}


comparable to those at 9:00 $\mathrm{h}$ (Fig. 5a). The reduction of SPAD-502 values at 12:00 and 15:00 $\mathrm{h}$ was, on average, $3.62 \pm 0.03 \%$ relative to SPAD values at 9:00 $\mathrm{h}$; this percentage corresponded to a decrease in absolute SPAD-502 values that was, on average, $1.67 \pm 0.02$ SPAD units. In the N2 and N3 treatments, SPAD-502 values did not change significantly during the day (Fig. 5a).

With the MC-100 meter, CCI values changed statistically during the day, regardless of the $\mathrm{N}$ treatment $\left(\mathrm{RM}-\mathrm{ANOVAT}_{\text {Time } \times \mathrm{N}} \mathrm{P}=0.189\right.$; Table 2$)$. On average, CCI values were significantly higher at 15:00 (6.1\%) and 18:00 (6.4\%) hours than CCI values measured at 9:00 h (Fig. 5b), for the three $\mathrm{N}$ treatments. The increase in CCI values at 15:00 and 18:00 h corresponded to an absolute increase in CCI values of 3.2 and 3.5 units, respectively, relative to measurements at 9:00 h. CCI values measured at 12:00 were statistically comparable to those at 9:00 h (Fig. 5b).

\section{Effect of time of day on canopy reflectance sensors}

Values of NDVI, measured both with the GreenSeeker handheld sensor and the Crop Circle ACS-470 sensor, and of GNDVI and GVI, measured with the Crop Circle sensor (Fig. 6), were not affected by time of day (RM-ANOVA $_{\text {Time }} \mathrm{P}>0.1$ in all cases; Table 3). However, for GVI, the time of the day effect was marginal at $\mathrm{P}=0.057$

Fig. 5 Change in integrated SPAD (a) and CCI values (b) relative to $9: 00 \mathrm{~h}(\%)$, in a sweet pepper crop grown in greenhouse. In (a), different lowercase letters show significant differences, at $\mathrm{P}<0.05$, between time of day within each $\mathrm{N}$ treatment, after LSD posthoc tests. In (b), different upper-case letters on $\mathrm{x}$-axis show significant differences between time of day, regardless of $\mathrm{N}$ treatment. Error bars show standard error
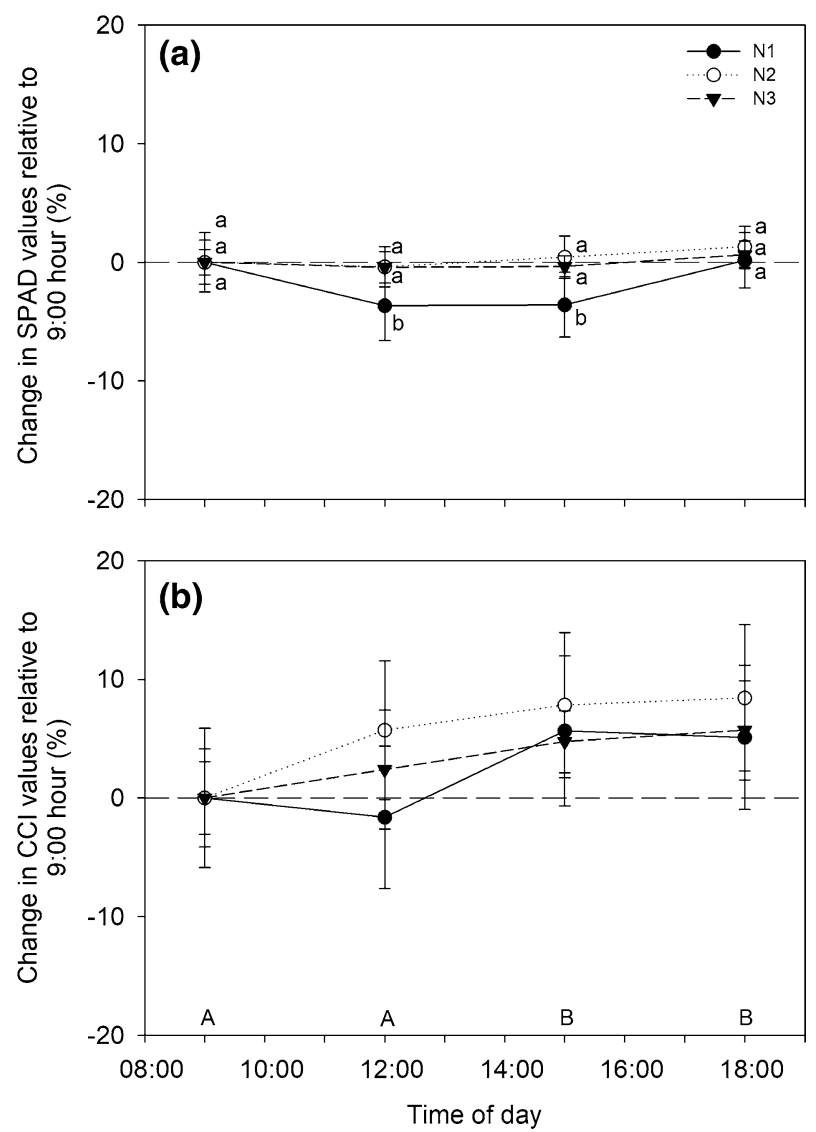

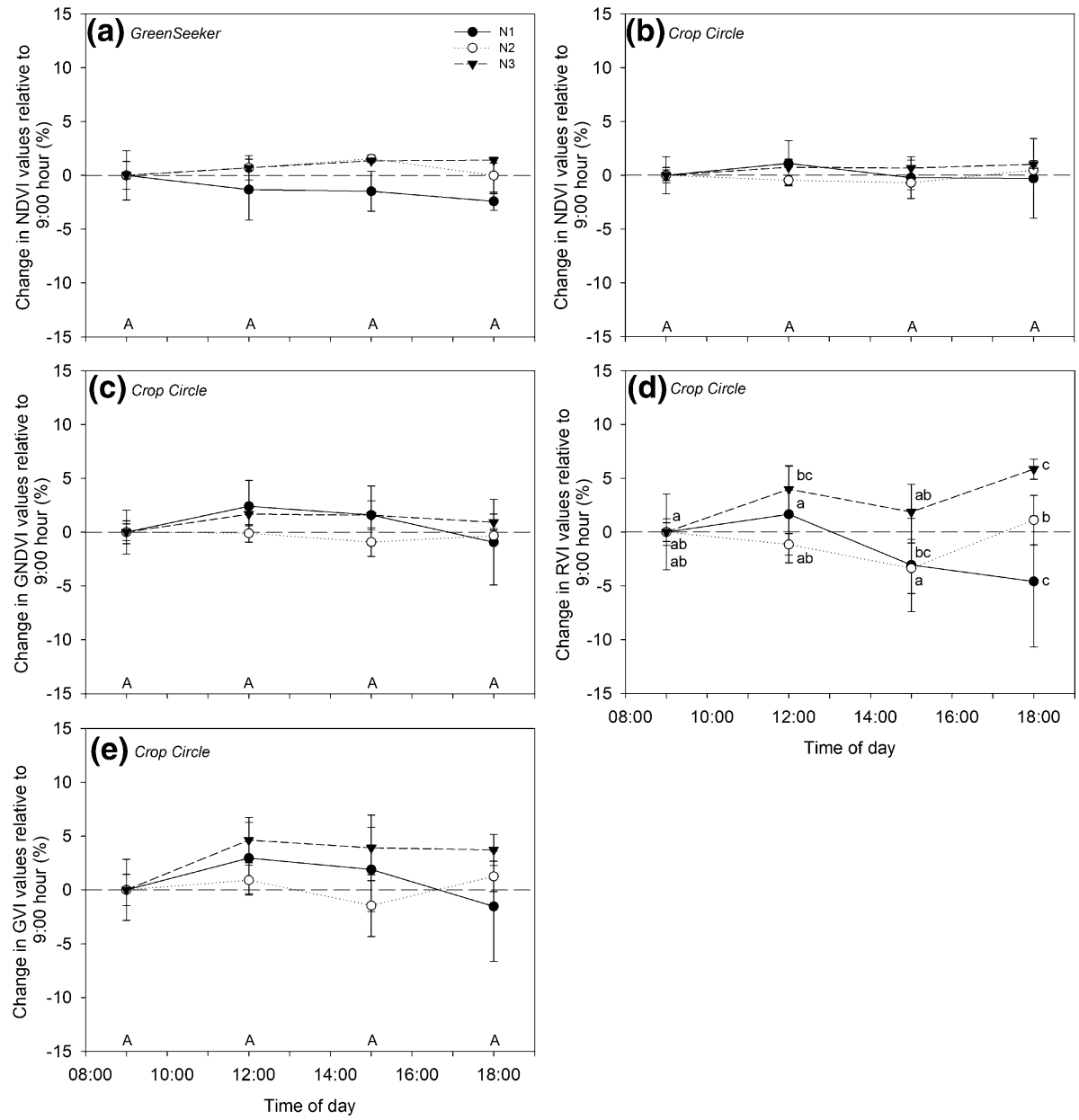

Fig. 6 Change in integrated NDVI values, measured with the GreenSeeker handheld sensor (a) and with the Crop Circle ACS-470 sensor (b), and of integrated GNDVI (c), RVI (d) and GVI (e) values, measured with the Crop Circle sensor, relative to 9:00 $\mathrm{h}(\%)$, in a sweet pepper crop grown in greenhouse. In $\mathbf{a}, \mathbf{b}, \mathbf{c}$ and e, same upper-case letters on the $\mathrm{x}$-axis show not significant differences, at $\mathrm{P}<0.05$, between time of day, regardless of $\mathrm{N}$ treatment. In $\mathbf{d}$, different lower-case letters show significant differences between time of day within each $\mathrm{N}$ treatment. Error bars show standard error

(Table 3). There was no interaction between time of day and $\mathrm{N}$ treatment in NDVI, GNDVI and GVI (P>0.1 in all cases; Table 3). Values of RVI, measured with the Crop Circle ACS-470 sensor, statistically changed during the day depending on $\mathrm{N}$ treatment (RM-ANOVA Time $\times \mathrm{N}_{\mathrm{N}} \mathrm{P}=0.008$; Table 3 ). In the $\mathrm{N} 1$ treatment, RVI values at 18:00 h were significantly $4.6 \%$ less than values at 9:00 h (Fig. 6d). This percentage corresponded to an absolute decrease in RVI values of 0.32 units. RVI values measured at 12:00 and 15:00 $\mathrm{h}$ were statistically comparable to RVI values at 9:00 h. In the $\mathrm{N} 3$ treatment, RVI values at 12:00 and 18:00 h were significantly 4.0 and 5.8\% higher, respectively, than RVI values measured at 9:00 h. These percentages corresponded to an increase in absolute RVI values of 0.47 and 0.68 units, respectively. RVI values 
Table 3 Repeated-measure analysis of variance (RM-ANOVA) testing the effect of nitrogen treatment and time of day on change in integrated NDVI values, measured with the GreenSeeker handheld sensor and with the Crop Circle ACS-470 sensor, and integrated GNDVI, RVI and GVI values, measured with the Crop Circle sensor, relative to 9:00 h, in a sweet pepper crop grown in a greenhouse

\begin{tabular}{|c|c|c|c|c|c|c|c|c|c|c|c|}
\hline \multirow[t]{2}{*}{ Effect } & \multirow[t]{2}{*}{ df } & \multicolumn{2}{|c|}{$\begin{array}{l}\text { NDVI Green- } \\
\text { Seeker }\end{array}$} & \multicolumn{2}{|c|}{$\begin{array}{l}\text { NDVI Crop } \\
\text { Circle }\end{array}$} & \multicolumn{2}{|c|}{$\begin{array}{l}\text { GNDVI Crop } \\
\text { Circle }\end{array}$} & \multicolumn{2}{|c|}{$\begin{array}{l}\text { RVI Crop } \\
\text { Circle }\end{array}$} & \multicolumn{2}{|c|}{$\begin{array}{l}\text { GVI Crop } \\
\text { Circle }\end{array}$} \\
\hline & & $\mathrm{F}$ & $P$ & $\mathrm{~F}$ & $\mathrm{p}$ & $\mathrm{F}$ & $\mathrm{p}$ & $\mathrm{F}$ & $\mathrm{p}$ & $\mathrm{F}$ & $\mathrm{P}$ \\
\hline Block & 3 & 0.44 & 0.733 & 1.11 & 0.417 & 0.80 & 0.538 & 0.96 & 0.471 & 0.58 & 0.650 \\
\hline Nitrogen $(\mathrm{N})$ & 2 & 0.86 & 0.469 & 0.09 & 0.916 & 0.17 & 0.848 & 0.69 & 0.536 & 0.30 & 0.751 \\
\hline Time $(\mathrm{T})$ & 3 & 0.31 & 0.816 & 0.36 & 0.780 & 2.47 & 0.095 & 3.26 & 0.046 & 3.01 & 0.057 \\
\hline $\mathrm{N} \times \mathrm{T}$ & 6 & 0.78 & 0.599 & 0.52 & 0.790 & 1.51 & 0.231 & 4.27 & 0.008 & 2.11 & 0.102 \\
\hline Error & 18 & & & & & & & & & & \\
\hline
\end{tabular}

measured at 15:00 h were statistically comparable to RVI values at 9:00 h (Fig. 6d). In the N2 treatment, there was no significant variation of RVI values during the day (Fig. 6d).

\section{Discussion}

\section{Effect of nitrogen on chlorophyll meter and canopy reflectance measurements}

Measurements of both chlorophyll meters, the SPAD-502 and MC-100, and the vegetation indices measured with the GreenSeeker handheld sensor (i.e. NDVI) and the Crop Circle ACS-470 sensor (i.e. NDVI, GNDVI, RVI and GVI), were all responsive to N treatments in sweet pepper. All chlorophyll meter measurements and vegetation indices increased with $\mathrm{N}$ addition and were significantly different between the three $\mathrm{N}$ treatments. These observations demonstrate that the two chlorophyll meters and two reflectance sensors can be used to differentiate very different $\mathrm{N}$ nutrition in sweet pepper, such as the very excessive $\mathrm{N}$ treatment (N3) from the conventional $\mathrm{N}$ treatment (N2). This is notable, because proximal optical sensors have been reported to lose sensitivity and have a tendency for saturation responses under conditions of high $\mathrm{N}$ application (Padilla et al. 2018a, c; Thompson et al. 2017).

The results of this study with sweet pepper are in agreement with numerous studies that reported that chlorophyll meters can be used to differentiate $\mathrm{N}$ nutrition and to assess crop N status in vegetable crops, such as fresh tomato (Padilla et al. 2015; $\mathrm{Wu}$ et al. 2012), processing tomato (Fitzgerald 2010; Gianquinto et al. 2006), muskmelon (Padilla et al. 2014), cucumber (Padilla et al. 2017a), sweet pepper (Parry et al. 2014), and potato (Gianquinto et al. 2004; Olivier et al. 2006). Regarding the canopy reflectance sensors, the capacity of the vegetation indices to differentiate $\mathrm{N}$ nutrition in sweet pepper, observed in the current study, is consistent with results with processing tomato (Gianquinto et al. 2011a), indeterminate tomato for fresh consumption (Padilla et al. 2015), hydroponically-grown (Yang et al. 2010) and soil-grown (Padilla et al. 2017b) cucumber, and in muskmelon (Padilla et al. 2014). 


\section{Effect of time of day on chlorophyll meters}

The present study found that measurements with the SPAD-502 meter in the N1 treatment were significantly lower at the time of maximum solar radiation and PAR, compared to early morning and evening measurements. Measurements in the evening were comparable to those made early morning, despite that the air temperature was appreciably higher in the evening (Fig. 1). These observations suggest that solar radiation had a statistically significant effect on relative chlorophyll measurements made with the SPAD-502 meter in greenhouse-grown sweet pepper, which is consistent with previous studies (Hoel and Solhaug 1998; Martínez and Guiamet 2004; Xiong et al. 2015). This effect is believed to be caused by modifications in chlorophyll distribution within leaves during the day which can be attributed to changes in chloroplast arrangement in response to variations in solar irradiance (Nauš et al. 2010). Therefore, chlorophyll meter readings can be influenced by irradiance conditions before and during measurement (Hoel and Solhaug 1998; Williams et al. 2003). Under low irradiance, most chloroplasts are positioned along the top and bottom walls of the cells, perpendicular to the incident light (face position) to maximize light absorption. When exposed to high irradiance, they are more likely to be found along the sides of the cells to prevent light damage (Nauš et al. 2010; Williams et al. 2003). Movement to the high-irradiance position is sometimes called 'avoidance movement', because the chloroplasts move out of the most direct light, while movement to the low-irradiance position is often called 'accumulation', because chloroplasts accumulate to increase light absorption (Williams et al. 2003).

The decline of SPAD-502 values at midday in the N1 treatment was, in absolute terms, slight, being on average $1.7 \pm 0.02$ SPAD units. From a practical perspective, this decline is negligible considering the range of SPAD units measured in the three $\mathrm{N}$ treatments of this study. SPAD-502 measurements were 13.2 and 16.9 SPAD units higher in both the conventional N2 and very excessive N3 treatments, respectively, compared to measurements in the very deficient N1 treatment. This range of SPAD readings is much larger than the diurnal decline of SPAD-502 measurements observed in the current study. Therefore, it is not strictly necessary that measurements with this sensor, in greenhouse-grown sweet pepper, are made at a particular time of the day. However, following a sampling protocol within a restricted time period is recommended to maximize homogeneity of measurement (Padilla et al. 2018c).

The magnitude of the time of day effect on SPAD-502 measurements in the N1 treatment, in the present study, was notably less than reported in previous studies. The $3.6 \%$ decline of SPAD values detected at midday in this study contrasted with the reported decreases of 5-8\% in winter wheat (Hoel and Solhaug 1998; Martínez and Guiamet 2004), $13 \%$ in rice (Xiong et al. 2015), 15\% in Oxalis acetosella (Hoel and Solhaug 1998), 16\% in tobacco (Nauš et al. 2010), and 28\% in soybean (Xiong et al. 2015). The influence of solar irradiance on chlorophyll meter measurements may be a species-specific effect that depends on species adaptation to high irradiance (Mamrutha et al. 2017; Xiong et al. 2015). The slight irradiance effect in sweet pepper may be due to adaptation of this species to high irradiance. Additionally, solar radiation values in the greenhouse where the study was conducted are typically 20-60\% (depending on whitewashing) of external values (Padilla et al. 2014, 2015, 2016). These values are well within the ranges recorded in commercial plastic greenhouses of the area (Castilla 2013; Valera-Martínez et al. 2016). Without the greenhouse plastic cover, the relative effect of time of day on SPAD-502 readings may have been higher. 
Unlike the very deficient N1 treatment, there was no time of day effect on SPAD-502 values in the conventional $\mathrm{N} 2$ and very excessive N3 treatments. A very similar finding was also reported for rice and soybean by Xiong et al. (2015). These authors reported that there was no significant diurnal variation in SPAD-502 measurements of plants supplemented with $\mathrm{N}$, but that SPAD measurements of plants that did not receive supplemental $\mathrm{N}$ were significantly lower at midday. Xiong et al. (2015) suggested that chloroplasts enlarged under high $\mathrm{N}$ conditions, occupying almost the entire cell space, which inhibited chloroplast movement at midday. For the sweet pepper crop, in the present study, data are not available of chloroplast size or chloroplast cell coverage. The work by Xiong et al. (2015) and the findings of the present study suggest that the effects of time of day on SPAD readings are related to crop $\mathrm{N}$ status.

For the MC-100 meter, CCI values measured at 9:00 and 12:00 h were comparable, and relatively higher values were measured at 15:00 and 18:00 h. These findings are not consistent with the decline of SPAD-502 readings at midday observed in the present study and other studies (Hoel and Solhaug 1998; Martínez and Guiamet, 2004; Nauš et al. 2010; Xiong et al. 2015). To our knowledge, this is first report of differential response to time of day between two chlorophyll meters, in this case, the SPAD-502 and the MC-100 meters. Previously, Mamrutha et al. (2017) found that response of various chlorophyll meters (SPAD-502, atLEAF + and CCM-200) to solar radiation was equal in six spring wheat genotypes. We cannot explain the difference between the SPAD-502 and the MC-100 meters observed in the present study. Measurements with the two meters were made immediately one after the other, on the same location of the same leaf. In addition, the two sensors measure red and NIR radiation absorbance at very similar wavelengths, i.e. at $650 \mathrm{~nm}$ and $940 \mathrm{~nm}$ in SPAD-502 meter, and at $653 \mathrm{~nm}$ and $931 \mathrm{~nm}$ in the MC-100 meter. It is difficult to explain the different results between the two sensors. The major different between them is that the measurement area of the SPAD-502 meter is considerably smaller than that of the MC-100 meter (i.e. 6 versus $64 \mathrm{~mm}^{2}$ ); however, it is difficult to understand how this would cause the observed differences in measurement.

The increase of CCI values in the afternoon and evening was, on average, $6.2 \pm 0.2 \%$ relative to CCI values in early morning and midday. In absolute terms, this represented an increase in CCI values of $3.3 \pm 0.1$ units. This increase can be considered small from a practical point of view, as the range of CCI values measured between the three $\mathrm{N}$ treatments of this study was considerably larger. CCI values measured in the conventional $\mathrm{N} 2$ and very excessive $\mathrm{N} 3$ treatments were 30.0 and 43.9 units higher, respectively, than those measured in the very deficient N1 treatment, and CCI values measured in the very excessive N3 treatment were 14.1 units higher than those measured in the conventional $\mathrm{N} 2$ treatment. The difference in measured CCI values between the three $\mathrm{N}$ treatments was well above the increase of CCI values in the afternoon and evening. Therefore, given these results, it is not justified that measurements with this sensor, with sweet pepper grown in greenhouse, be made at a particular time of the day. However, as with all optical sensors, a consistent sampling protocol, including the range of measurement times, is recommended to enhance homogeneity of measurement (Padilla et al. 2018c).

\section{Effect of time of day on canopy reflectance sensors}

Values of NDVI, measured both with the GreenSeeker handheld and the Crop Circle ACS470, and of GNDVI and GVI, measured with the Crop Circle, were not affected statistically by time of day in any of the $\mathrm{N}$ treatments of this study. These results support the 
long-stated assumption that active canopy reflectance sensors can be used under any irradiance conditions without alterations in vegetation indices measured (Solari et al. 2008). Various previous studies with wheat and cotton have reported that there were not time of day or irradiance effects on canopy reflectance measurements (Fitzgerald 2010; Kipp et al. 2014; Oliveira and Scharf 2014).

Since both the GreenSeeker handheld and the Crop Circle ACS-470 sensors are active sensors with their own light source, time of day effects on these sensors were expected to occur only if they were able to detect the changes in the distribution of leaf chlorophyll that occurred during the day, as discussed for chlorophyll meters. However, unlike chlorophyll meters that measure a very localized area of a leaf, the area of measurement of these reflectance sensors is much larger and integrates not only leaves but also stems, fruits and air gaps within the crop structure. It is reasonable that sensors that integrate different tissues and air gaps have reduced sensitivity to detect changes in chlorophyll distribution that occur during the day mostly at the leaf level.

There are reports of slight effects of solar irradiance on measurements of active canopy reflectance sensors, particularly the GreenSeeker handheld sensor. Several studies reported effects in turfgrass (Kim et al. 2012), cotton (Oliveira and Scharf 2014) and soybean cultivars (Teixeira Crusiol et al. 2017). Although the literature suggests that measurements of the GreenSeeker handheld sensor are more sensitive to changes in solar radiation during the day than active Crop Circle sensors; in the present study, no irradiance effect on GreenSeeker handheld measurements was observed.

In the present study, the behavior of simple ratio vegetation indices, such as RVI and GVI, in relation to time of day effects tended to differ from the normalized vegetation indices measured with the Crop Circle ACS-470, i.e. NDVI and GNDVI. While NDVI and GNDVI were not affected by time of day, GVI was marginally affected and RVI was significantly affected but these effects were contingent on the $\mathrm{N}$ treatment. In particular, in the very deficient N1 treatment, RVI values were nearly 5\% lower in the evening than those measured in early morning. In the very excessive N3 treatment, RVI values were approximately $5 \%$ higher at midday and in the evening compared to early morning. These results are inconclusive since contrary time of day effects were observed in the N1 and N3 treatments. Given that the variation in RVI values during the day was only 5\%, it may be that the effects observed in this vegetation index were due to measurement variability. In fact, normalized indices such NDVI and GNDVI, unlike simple ratio indices such as RVI and GVI, enable compensation for effects of non-uniform illumination, i.e. different amounts of incoming light and varying illumination angles (Bannari et al. 1995; Jones and Vaughan 2010). These are often the underlying factors behind aspect and topography effects in remote sensing (Jones and Vaughan 2010; Mason 2004). In our study in a greenhouse crop, the uneven distribution, inclination and orientation of foliage in the sweet pepper foliage may have resulted in similar effects to those of topography and aspect that are sometimes observed in remote sensing, leading to larger variability and inconsistent results with RVI.

\section{Conclusions}

Overall, this study showed that measurements of the SPAD-502 and MC-100 chlorophyll meters, and vegetation indices measured with the GreenSeeker handheld sensor (i.e. NDVI) and Crop Circle ACS-470 sensor (i.e. NDVI, GNDVI, RVI and GVI), were responsive to 
$\mathrm{N}$ treatments and can be used to differentiate appreciably different $\mathrm{N}$ nutrition in sweet pepper.

Time of day, particularly midday and the afternoon, had an effect on relative chlorophyll measurements made with the SPAD-502 meter, but only in the very deficient N1 treatment. This suggested that the effects of time of day on SPAD-502 readings were related to crop $\mathrm{N}$ status. Nevertheless, this effect was slight and of little practical relevance for sweet pepper in greenhouse. For the MC-100 meter, a slight increase in CCI values was obtained in measurements made in the afternoon and the evening, compared to early morning measurements, regardless of the $\mathrm{N}$ treatment. This time of day effect on the MC-100 meter measurements is small for practical use on farm of this meter with greenhouse-grown sweet pepper.

Values of NDVI, measured both with the GreenSeeker handheld and the Crop Circle ACS-470, and of GNDVI, measured with the Crop Circle, were not affected by time of day in any of the $\mathrm{N}$ treatments of this study. These results support the assumption that these two active canopy reflectance sensors can be used under any radiation conditions without alterations in the vegetation indices measured.

Acknowledgements The Spanish Ministry of Economy and Competitiveness funded this work (Project AGL2015-67076-R). FMP was supported by a Ramón y Cajal grant (RYC-2014-15815) and RdS by a FPI grant (BES-2016-076706), both from the Spanish Ministry of Economy and Competitiveness. We thank Antonio Alfano for his excellent assistance in the field, and the staff of the Experimental Station of the University of Almeria for their excellent work with the experimental crop.

Open Access This article is distributed under the terms of the Creative Commons Attribution 4.0 International License (http://creativecommons.org/licenses/by/4.0/), which permits unrestricted use, distribution, and reproduction in any medium, provided you give appropriate credit to the original author(s) and the source, provide a link to the Creative Commons license, and indicate if changes were made.

\section{References}

Bannari, A., Morin, D., Bonn, F., \& Huete, A. R. (1995). A review of vegetation indices. Remote Sensing Reviews, 13, 95-120.

Birth, G. S., \& McVey, G. R. (1968). Measuring the color of growing turf with a reflectance spectrophotometer. Agronomy Journal, 60, 640-643.

Cameron, K. C., Di, H. J., \& Moir, J. L. (2013). Nitrogen losses from the soil/plant system: A review. Annals of Applied Biology, 162, 145-173.

Castilla, N. (2013). Greenhouse technology and management (2nd ed.). Oxfordshire, UK: CABI.

Debaeke, P., Rouet, P., \& Justes, E. (2006). Relationship between the normalized SPAD index and the nitrogen nutrition index: Application to durum wheat. Journal of Plant Nutrition, 29, 75-92.

Fitzgerald, G. J. (2010). Characterizing vegetation indices derived from active and passive sensors. International Journal of Remote Sensing, 31, 4335-4348.

Fox, R. H., \& Walthall, C. L. (2008). Crop monitoring technologies to assess nitrogen status. In J. S. Schepers \& W. R. Raun (Eds.), Nitrogen in Agricultural Systems, Agronomy Monograph No. 49 (pp. 647674). Madison, WI, USA: American Society of Agronomy, Crop Science Society of America, Soil Science Society of America.

Gianquinto, G., Goffart, J. P., Olivier, M., Guarda, G., Colauzzi, M., Dalla Costa, L., et al. (2004). The use of hand-held chlorophyll meters as a tool to assess the nitrogen status and to guide nitrogen fertilization of potato crop. Potato Research, 47, 35-80.

Gianquinto, G., Orsini, F., Fecondini, M., Mezzetti, M., Sambo, P., \& Bona, S. (2011a). A methodological approach for defining spectral indices for assessing tomato nitrogen status and yield. European Journal of Agronomy, 35, 135-143.

Gianquinto, G., Orsini, F., Sambo, P., \& Paino D'Urzo, M. (2011b). The use of diagnostic optical tools to assess nitrogen status and to guide fertilization of vegetables. HortTechnology, 21, 287-292. 
Gianquinto, G., Sambo, P., \& Borsato, D. (2006). Determination of SPAD threshold values for the optimisation of nitrogen supply in processing tomato. Acta Horticulturae, 700, 159-166.

Gitelson, A. A., Kaufman, Y. J., \& Merzlyak, M. N. (1996). Use of a green channel in remote sensing of global vegetation from EOS- MODIS. Remote Sensing of Environment, 58, 289-298.

Güler, S., Ibrikci, H., \& Büyük, G. (2006). Effects of different nitrogen rates on yield and leaf nutrient contents of drip-fertigated and greenhouse-grown cucumber. Asian Journal of Plant Sciences, 5, 657-662.

Hatfield, J. L., Gitelson, A. A., Schepers, J. S., \& Walthall, C. L. (2008). Application of spectral remote sensing for agronomic decisions. Agronomy Journal, 100, S117-S131.

Hoel, B. O., \& Solhaug, K. A. (1998). Effect of irradiance on chlorophyll estimation with the Minolta SPAD-502 leaf chlorophyll meter. Annals of Botany, 82, 389-392.

Holland, K. H., \& Schepers, J. S. (2013). Use of a virtual-reference concept to interpret active crop canopy sensor data. Precision Agriculture, 14, 71-85.

Jones, H. G., \& Vaughan, R. A. (2010). Remote sensing of vegetation. New York, USA: Oxford University Press.

Kim, Y., Glenn, D. M., Park, J., Ngugi, H. K., \& Lehman, B. L. (2012). Characteristics of active spectral sensor for plant sensing. Transactions of the ASABE, 55, 293-301.

Kipp, S., Mistele, B., \& Schmidhalter, U. (2014). The performance of active spectral reflectance sensors as influenced by measuring distance, device temperature and light intensity. Computers and Electronics in Agriculture, 100, 24-33.

Mamrutha, H. M., Sharma, D., Sumanth Kumar, K., Venkatesh, K., Tiwari, V., \& Sharma, I. (2017). Influence of diurnal irradiance variation on chlorophyll values in wheat: A comparative study using different chlorophyll meters. National Academy Science Letters, 40, 221-224.

Martínez, D. E., \& Guiamet, J. J. (2004). Distortion of the SPAD 502 chlorophyll meter readings by changes in irradiance and leaf water status. Agronomie, 24, 41-46.

Mason, I. (2004). Remote sensing of the Earth's climate system. In L. K. Harra \& K. O. Mason (Eds.), Space Science (pp. 13-72). London, UK: Imperial Collegue Press (distributed by World Scientific Publisihing Co).

Meisinger, J. J., Schepers, J. S., \& Raun, W. R. (2008). Crop nitrogen requirement and fertilization. In J. S. Schepers \& W. R. Raun (Eds.), Nitrogen in Agricultural Systems, Agronomy Monograph No. 49 (pp. 563-612). Madison, WI, USA: American Society of Agronomy, Crop Science Society of America, Soil Science Society of America.

Monje, O. A., \& Bugbee, B. (1992). Inherent limitations of nondestructive chlorophyll meters: A comparison of two types of meters. HortScience, 27, 69-71.

Nauš, J., Prokopová, J., Řebíček, J., \& Špundová, M. (2010). SPAD chlorophyll meter reading can be pronouncedly affected by chloroplast movement. Photosynthesis Reserarch, 105, 265-271.

Neeteson, J. J. (1994). Nitrogen management for intensively grown arable crops and field vegetables. In P. Bacon (Ed.), Nitrogen Fertilization and the Environment (pp. 295-325). New York, USA: Marcel Dekker.

Oliveira, L. F., \& Scharf, P. C. (2014). Diurnal variability in reflectance measurements from cotton. Crop Science, 54, 1769-1781.

Ollinger, S. V. (2011). Sources of variability in canopy reflectance and the convergent properties of plants. New Phytologist, 189, 375-394.

Padilla, F. M., de Souza, R., Peña-Fleitas, M. T., Gallardo, M., Giménez, C., \& Thompson, R. B. (2018a). Different responses of various chlorophyll meters to increasing nitrogen supply in sweet pepper. Frontiers in Plant Science, 9, 1752.

Padilla, F. M., Gallardo, M., \& Manzano-Agugliaro, F. (2018b). Global trends in nitrate leaching research in the 1960-2017 period. Science of the Total Environment, 643, 400-413.

Padilla, F. M., Gallardo, M., Peña-Fleitas, M. T., de Souza, R., \& Thompson, R. B. (2018c). Proximal optical sensors for nitrogen management of vegetable crops: A review. Sensors, 18, 2083.

Padilla, F. M., Peña-Fleitas, M. T., Gallardo, M., Giménez, C., \& Thompson, R. B. (2017a). Derivation of sufficiency values of a chlorophyll meter to estimate cucumber nitrogen status and yield. Computers and Electronics in Agriculture, 141, 54-64.

Padilla, F. M., Peña-Fleitas, M. T., Gallardo, M., \& Thompson, R. B. (2015). Threshold values of canopy reflectance indices and chlorophyll meter readings for optimal nitrogen nutrition of tomato. Annals of Applied Biology, 166, 271-285.

Padilla, F. M., Peña-Fleitas, M. T., Gallardo, M., \& Thompson, R. B. (2016). Proximal optical sensing of cucumber crop N status using chlorophyll fluorescence indices. European Journal of Agronomy, 73, 83-97. 
Padilla, F. M., Peña-Fleitas, M. T., Gallardo, M., \& Thompson, R. B. (2017b). Determination of sufficiency values of canopy reflectance vegetation indices for maximum growth and yield of cucumber. European Journal of Agronomy, 84, 1-15.

Padilla, F. M., Teresa Peña-Fleitas, M., Gallardo, M., \& Thompson, R. B. (2014). Evaluation of optical sensor measurements of canopy reflectance and of leaf flavonols and chlorophyll contents to assess crop nitrogen status of muskmelon. European Journal of Agronomy, 58, 39-52.

Parry, C., Blonquist, J. M., \& Bugbee, B. (2014). In situ measurement of leaf chlorophyll concentration: analysis of the optical/absolute relationship. Plant, Cell and Environment, 37, 2508-2520.

Peñuelas, J., Gamon, J. A., Fredeen, A. L., Merino, J., \& Field, C. B. (1994). Reflectance indices associated with physiological changes in nitrogen- and water-limited sunflower leaves. Remote Sensing of Environment, 48, 135-146.

Piekielek, W. P., Fox, R. H., Toth, J. D., \& Macneal, K. E. (1995). Use of a chlorophyll meter at the early dent stage of corn to evaluate nitrogen sufficiency. Agronomy Journal, 87, 403-408.

Read, J. J., Tarpley, L., McKinion, J. M., \& Reddy, K. R. (2002). Narrow-waveband reflectance ratios for remote estimation of nitrogen status in cotton. Journal of Environmental Quality, 31, 1442-1452.

Samborski, S. M., Tremblay, N., \& Fallon, E. (2009). Strategies to make use of plant sensors-based diagnostic information for nitrogen recommendations. Agronomy Journal, 101, 800-816.

Schröder, J. J., Neeteson, J. J., Oenema, O., \& Struik, P. C. (2000). Does the crop or the soil indicate how to save nitrogen in maize production? Reviewing the state of the art. Field Crops Research, 66, 151-164.

Scotford, I. M., \& Miller, P. C. H. (2005). Applications of spectral reflectance techniques in northern European cereal production: A review. Biosystems Engineering, 90, 235-250.

Sellers, P. J. (1985). Canopy reflectance, photosynthesis and transpiration. International Journal of Remote Sensing, 6, 1335-1372.

Solari, F., Shanahan, J., Ferguson, R., Schepers, J., \& Gitelson, A. (2008). Active sensor reflectance measurements of corn nitrogen status and yield potential. Agronomy Journal, 100, 571-579.

Soto, F., Gallardo, M., Thompson, R. B., Peña-Fleitas, M. T., \& Padilla, F. M. (2015). Consideration of total available $\mathrm{N}$ supply reduces $\mathrm{N}$ fertilizer requirement and potential for nitrate leaching loss in tomato production. Agriculture, Ecosystems \& Environment, 200, 62-70.

Teixeira Crusiol, L. G., Corrêa Carvalho, J. F., Ribeiro Sibaldelli, R. N., Neiverth, W., Do Rio, A., Ferreira, L. C., et al. (2017). NDVI variation according to the time of measurement, sampling size, positioning of sensor and water regime in different soybean cultivars. Precision Agriculture, 18, 470-490.

Thenkabail, P. S., Smith, R. B., \& De Pauw, E. (2002). Evaluation of narrowband and broadband vegetation indices for determining optimal hyperspectral wavebands for agricultural crop characterization. Photogrammetric Engineering and Remote Sensing, 68, 607-621.

Thompson, R. B., Martinez-Gaitan, C., Gallardo, M., Gimenez, C., \& Fernandez, M. D. (2007). Identification of irrigation and $\mathrm{N}$ management practices that contribute to nitrate leaching loss from an intensive vegetable production system by use of a comprehensive survey. Agricultural and Water Management, 89, 261-274.

Thompson, R. B., Tremblay, N., Fink, M., Gallardo, M., \& Padilla, F. M. (2017). Tools and strategies for sustainable nitrogen fertilisation of vegetable crops. In F. Tei, S. Nicola, \& P. Benincasa (Eds.), Advances in Research on Fertilization Management in Vegetable Crops (pp. 11-63). Heidelberg, Germany: Springer.

Tremblay, N., Wang, Z., \& Cerovic, Z. G. (2012). Sensing crop nitrogen status with fluorescence indicators. A review. Agronomy for Sustainable Development, 32, 451-464.

Usha, K., \& Singh, B. (2013). Potential applications of remote sensing in horticulture-A review. Scientia Horticulturae, 153, 71-83.

Valera-Martínez, D. L., Belmonte-Ureña, L. J., Molina-Aiz, F. D., \& López-Martínez, A. (2016). Greenhouse agriculture in Almeria. A comprehensive techno-economic analysis, Serie Económica 27. Almeria, Spain: Cajamar Caja Rural.

Williams, W. E., Gorton, H. L., \& Witiak, S. M. (2003). Chloroplast movements in the field. Plant, Cell and Environment, 26, 2005-2014.

Xiong, D., Chen, J., Yu, T., Gao, W., Ling, X., Li, Y., et al. (2015). SPAD-based leaf nitrogen estimation is impacted by environmental factors and crop leaf characteristics. Scientific Reports, 5, 13389.

Yang, W., Li, M., \& Nick, S. (2010). Estimating nitrogen content of cucumber leaves based on NIR spectroscopy. Sensor Letters, 8, 145-150.

Zhu, J., Tremblay, N., \& Liang, Y. (2011). A corn nitrogen status indicator less affected by soil water content. Agronomy Journal, 103, 890-898.

Publisher's Note Springer Nature remains neutral with regard to jurisdictional claims in published maps and institutional affiliations. 


\section{Affiliations}

Francisco M. Padilla ${ }^{1,2}$ D $\cdot$ Romina de Souza $^{1} \cdot$ M. Teresa Peña-Fleitas ${ }^{1} \cdot$ Rafael Grasso $^{3}$. Marisa Gallardo ${ }^{1,2} \cdot$ Rodney B. Thompson ${ }^{1,2}$

1 Department of Agronomy, University of Almeria, Carretera de Sacramento s/n, La Cañada, 04120 Almería, Spain

2 CIAIMBITAL Research Centre for Mediterranean Intensive Agrosystems and Agrifood Biotechnology, University of Almeria, Almería, Spain

3 Estación Experimental INIA Salto Grande, Instituto Nacional de Investigación Agropecuaria (INIA), Camino al Terrible s/n, 50000 Salto, Uruguay 